УДК 793.3:394.3(477.54/.62)

DOI: $10.31866 / 2616-7646.2 .1 .2019 .172185$

\title{
ДОСВІД ЕТНОХОРЕОЛОГІЇ В ОПАНУВАННІ СТИЛІСТИКИ СЛОБОЖАНСЬКОГО ТАНЦЮВАЛЬНОГО ФОЛЬКЛОРУ
}

\author{
Мостова Ірина Сергіївна, \\ викладачка, \\ Харківська державна академія культури, \\ Харків, Україна, \\ https://orcid.org/0000-0003-3377-235X, \\ pisergeevna2808agmail.com
}

\begin{abstract}
Мета дослідження - проаналізувати й систематизувати передові методологічні розроблення в галузі етнохореології в контексті їх застосування під час концептуалізації стилістики слобожанського танцювального фольклору. Методологія. 3 огляду на історико-культурологічні особливості слобожанського танцювального фольклору як феномену української традиційної культури основними стали теоретичний, системний, аналітичний та культурологічний методи дослідження, які дали змогу опанувати методологічні досягнення в галузі етнохореології та виявити можливості їхнього використання в процесі дослідження танцювального канону Слобожанщини. Наукова новизна статті полягає в екстраполяції новітніх методів етнохореології відомих вітчизняних та зарубіжних етнохореологів під час дослідження стилістичних особливостей фольклорних танців Слобожанщини. Уперше проаналізовано алгоритм використання новітніх етнохореологічних методів у процесі опанування стилістикою слобожанського танцювального канону. Висновки. Проаналізовано передові досягнення українських, канадських, європейських та вірменських вчених у галузі етнохореології, специфіка яких полягає у використанні методологічних принципів математики, лінгвістики та музикології (термінологічні, квалітативні, квантитативні методи дослідження). Виявлено особливості впровадження методології суміжних видів мистецтв у процес дослідження стилістичних особливостей фольклорних танців різних етнічних та етнографічних груп населення, що полягає в необхідності створення чіткої хореографічної партитури, виведення «хореографічної стопи». Впроваджені новітні методологічні розробки дали підстави науково обгрунтувати концептуалізацію танцювального канону фольклорних танців Слобожанщини, що втілюється у композиції танцювального твору та характері виконання танцювальних рухів. Доцільність методологічних розробок підтверджена актуальними висновками щодо побутування типових ознак у стилістиці слобожанського танцювального фольклору.
\end{abstract}

Ключові слова: етнохореологічна методологія; стилістика фольклорного танцю; народний танець Слобожанщини; танцювальний канон. 


\section{ОПЫТ ЭТНОХОРЕОЛОГИИ В ОСМЫСЛЕНИИ СТИЛИСТИКИ СЛОБОЖАНСКОГО ТАНЦЕВАЛЬНОГО ФОЛЬКЛОРА}

Мостовая Ирина Сергеевна, преподаватель,

Харьковская государственная академия культуры,

Харьков, Украина, https://orcid.org/0000-0003-3377-235X, pisergeevna2808agmail.com

Цель исследования - проанализировать и систематизировать передовые методологические разработки в области этнохореологии в контексте их применения во время концептуализации стилистики слобожанского танцевального фольклора. Методология. Учитывая историко-культурологические особенности исследования слобожанского танцевального фольклора как феномена украинской традиционной культуры, основными стали теоретический, системный, аналитический и культурологический методы исследования, которые позволили овладеть методологическими достижениями в области этнохореологии и определить возможности их использования в процессе исследования танцевального канона Слобожанщины. Научная новизна статьи заключается в экстраполяции новейших методов етнохореологии известных отечественных и зарубежных етнохореологов в ходе исследования стилистических особенностей фольклорных танцев Слобожанщины. Впервые проанализовано алгоритм использования новейших этнохореологических методов в процессе овладения стилистикой слобожанского танцевального канона. Выводы. Проанализированы передовые достижения украинских, канадских, европейских и армянских ученых в области этнохореологии, специфика которых заключается в использовании методологических принципов математики, лингвистики и музыкологии (терминологические, квалитативные, квантитативные методы исследования). Выявлены особенности внедрения методологии смежных видов

\section{THE EXPERIENCE OF ETHNOCHOREOLOGY IN UNDERSTANDING THE STYLISTICS OF SLOBOZHANSKY DANCE FOLKLORE}

\author{
Iryna Mostova, \\ lecturer, \\ Kharkiv State Academy of Culture, \\ Kharkiv, Ukraine, \\ https://orcid.org/0000-0003-3377-235X, \\ pisergeevna2808damail.com
}

The purpose of the research is to analyze and systematize the advanced methodological developments in the field of ethnochoreology in the context of their use in the process of conceptualizing the Slobozhanskyi dance folklore stylistics. Methodology. Taking into account the historical and cultural studies of the Slobozhansky dance folklore as a phenomenon in Ukrainian traditional culture, the main methods were: theoretical, systemic, analytical, and cultural. The selected methods allowed to master the international methodological achievements in the field of ethnochoreology and to determine the possibilities of their use in the study of the dance canon of Slobozhanshchina. The scientific novelty of the article lies in the extrapolation of the newest methods of ethno-choreology of wellknown domestic and foreign ethno-choreologists in the study of the stylistic features of the folklore dances of Slobozhanshchina. For the first time, the algorithm of using the newest ethno-choreological methods in the process of mastering the stylistics of the Slobozhansky dance canon was analyzed. Conclusions. The advanced achievements of Ukrainian, Canadian, European and Armenian scientists in the field of ethno-choreology, the specificity of which is to use the methodological principles of mathematics, linguistics and musicology (terminological, qualitative, quantitative research methods) are analyzed. The features of the introduction of the methodology of related arts in the process of research of the stylistic features of folklore dances of different ethnic and ethnographic groups of the population are revealed, which is the 
искусств в процесс исследования стилистических особенностей фольклорных танцев разных этнических и этнографических групп населения, что заключается в необходимости создания четкой хореографической партитуры, выведения «хореографической стопы». Внедренные новейшие методологические разработки позволили научно обосновать концептуализацию танцевального канона фольклорных танцев Слобожанщины, который воплощается в композиции танцевального произведения и характере исполнения танцевальных движений. Целесообразность методологических разработок подтверждена актуальными выводами относительно бытования типичных признаков в стилистике слобожанского танцевального фольклора.

Ключевые слова: этнохореологическая методология; стилистика фольклорного танца; народный танец Слобожанщины; танцевальный канон. need to create a clear choreographic score, deduce the "choreographic foot". The newest methodological developments introduced allowed to scientifically substantiate the conceptualization of the dance canon of the folklore dances of Slobozhanshchina, which is embodied in the composition of the dance work and the nature of the performance of dance movements. The expediency of methodological developments is confirmed by current conclusions regarding the existence of typical features in the style of Slobozhanskyi dance folklore.

Keywords: ethnorehorological methodology; stylistics of folklore dance; Slobozhanshchina folk dance; dance canon.

Актуальність теми дослідження. Етнохореологія як наукова галузь перебуває в процесі становлення, тому розроблення методологічної бази для етнохореологічних досліджень потребує постійного вдосконалення. У більшості сучасних етнохореологічних працях використовується загальнонаукова методологія, а розроблення спеціальних наукових методик займає другорядні позиції. У контексті опанування новітніми методиками вивчення особливостей етнічних танців актуалізує також необхідність їх безпосереднього залучення до процесу виявлення стилістичних особливостей танцювального канону слобожанських народних танців. Опанування методологічним досвідом передових етнохореологічних шкіл допоможе робити висновки стосовно стилістики танцювального фольклору на новому культурологічному рівні.

Аналіз останніх досліджень та публікацій. Розгляд наукових матеріалів з теми наукової статті дає підстави визначити такі дві групи: публікації, де автори звертаються до розв'язання проблеми недосконалості теоретико-методологічних основ хореології та етнохореології; дослідження й публікації, у яких практично застосовуються новітні методологічні підходи у вивченні танцю.

До вирішення методологічних і теоретичних проблем хореології неодноразово звертався О. Чепалов, зокрема в статтях «Проблеми якості наукового дослідження та достеменності його фахової спеціалізації» (Чепалов, 2016), «Хореологія як наука: культурологічні та мистецтвознавчі аспекти» (Чепалов, 2018). Дослідник порушує актуальні проблеми розвитку хореології в Україні, акцентує увагу на потребі вироблення єдиного термінологічного апарата й теоретичної бази, актуалі- 
зує важливість вивчення системи кодів зірних танцювальних практик. Д. Шариков у статтях «Стилістичні різновиди народного танцю в світі» (Шариков, 2014) та «Дефініція хореографічної культури: функції та система закономірностей існування» (Шариков, 2015) конкретизує деякі загальновживані терміни, але його тлумачення потребують збільшення культурологічного складника. Вчений уточнює дефініції «хореографічна культура», «онтологія танцю» та «хореологія». До уточнення поняття «хореографічна культура» вдається і А. Підлипська в статті «Тенденції розвитку наукових досліджень у галузі хореографічної культури в Україні». Розробленням методологічної бази етнохореології, а також уточненням дефініції «етнохореологія» займалася Н. Чілікіна у статті «Проблематика сучасної хореографічної освіти» (Чілікіна, 2015), де розглянуто специфіку впровадження синергетичного методу й соматичного підходу в процес вивчення різних танцювальних практик.

Безпосереднім впровадженням новітніх методик та підходів у вивчення народних танців займались і вітчизняні, і зарубіжні наукові школи. Під керівництвом А. Нагачевського сформувалася канадська школа української фольклористики. А. Нагачевський у статтях «Особливості української фольклористики в Канаді» (Нагачевський, \& Маєрчик, 2010), «Від національного до видовищного: про відродження українського народного танцю в Канаді» (Нагачевський, 2010) активно впроваджував термінологічний метод. Метод квантитативного аналізу хореографічного твору використовувала Н. Саргсян у праці «Про квантитативний метод аналізу хореографічних і музичних елементів (на прикладі музичнокінетографічних партитур С. С. Джуджева та С. С. Лісіціан)» (Саргсян, 2016), «Методи аналізу хореографічного опусу засобами термінів, що використовуються у музикознавстві» (Саргсян, 2015), а також Т. Новак у монографії «Народний танець в польському культурному каноні. Зародження, ґенеза, зміни» (Новак, 2016) та в статті «Польські народні танці як культурний канон - виникнення, генеза, зміни» (Новак, 2018). Окреслені наукові методи та підходи досі не були використані під час дослідження стилістики фольклорних танців Слобожанщини.

Мета дослідження - проаналізувати й систематизувати передові методологічні розроблення в галузі етнохореології в контексті їх застосування під час концептуалізації стилістики слобожанського танцювального фольклору.

Виклад основного матеріалу. Етнохореологія - академічна міждисциплінарна галузь досліджень, яка враховує всі танцювальні і структурні практики людського тіла, що трансформують культурні особливості етносу. Ця галузь хореології допомагає зрозуміти культурні традиції та досвід руху, який пропонують різні культури. Фактично, етимологія терміну «етнохореологія» позначає вивчення етнічних танців, передбачає дослідження народного танцю в контексті його етнічної приналежності та з урахуванням особливостей його етнологічного розвитку.

Етнохореологічні дослідження в Європі підтримуються багатьма науковими спільнотами та кафедрами закладів вищої освіти: курс з етнохореології в програмі Всесвітньої Ірландської академії музики й танцю, дослідницька група з етнохореології при Міжнародній раді із традиційної музики.

Зростання зацікавленості фахівців-дослідників вирішенням актуальних етнохореологічних питань обумовлюється загальною зорієнтованістю на переосмислення фольклорної спадщини. Захоплення народним танцювальним 
мистецтвом звертає увагу науковців на вирішення квестій (проблемних питань), пов’язаних із вивченням, збереженням, професійною трансформацією та сучасною інтерпретацією автентичних зразків. Окрім суто практичних питань, які входять до спектру інтересів етнохореології, важливими стають нагальні методологічні проблеми. Розроблення наукових підходів і методів знаходиться в процесі формування та самовизначення. Базисні методи дослідження актуальних етнохореологічних питань не знайшли чіткого окреслення в теоретичних напрацюваннях науковців, хоча $з$ їхньою допомогою можливо обгрунтувати концептуально важливі тези, вирішити важливі наукові завдання. Але залишається багато специфічних дослідницьких тем, що потребують використання методологічних підходів вужчої компетенції.

Сучасні етнохореологічні дослідження українського народного танцю виходять далеко за межі усталеного культурного канону. Для одержання комплексних результатів треба враховувати методологічні розроблення канадських фольклористів, які приділяють багато уваги вивченню етапів трансформації форм українського народного танцю канадської діаспори. Канадськими науковцямиетнохореологами розроблені наукові підходи до визначення семіотики українських народних танців, створені методи вивчення композиційних трансформації, що виникають внаслідок заміщення автентичних символів.

Значна увага серед іноземних етнохореологів до дослідження українського народного танцю обумовлюється розширенням української діаспори внаслідок кількох хвиль еміграції. Зберігаючи форми національних танців, керівники гуртів та самі виконавці стають учасниками процесу відродження українського народного танцю поза межами нашої держави. Важливість цього процесу підкреслюється більшою ймовірністю фіксації автентичних танцювальних зразків у культурній діаспорній традиції. Процес відродження народних танців поза межами осередку їх формування передбачає усвідомлення всіма учасниками процесу його історичності, тобто відрефлексовування автентичної традиції сучасниками.

Варто звернути увагу на роботи А. Нагачевського, які $\epsilon$ найбільш значущими. Так, у статті «Від національного до видовищного: про відродження українського народного танцю в Канаді» (Нагачевський, 2010) автор порушує чимало актуальних тем, серед яких такі: диференціація спрямування процесу відродження танцювальних форм; специфіка «академізації» українського народного танцю в Канаді; тенденції збереження семіотики народних танців. Окрім того, А. Нагачевський значно вдосконалює понятійний апарат, який стає базовим для подальших етнохореологічних досліджень у Канаді. Обгрунтованими термінологічними дефініціями користуються дослідники-фольклористи, чиї наукові дописи зосереджені на досліджені народних танців. До таких робіт можна віднести статтю В. Ріса «"Березнянка": на шляху до символізації» (Rees, 2010), в якій автор звертається до специфіки трансформації танцювального канону, що був утілений у народному танці, зафіксованому в с. Люта Закарпатської області.

У своїх дослідженнях А. Нагачевський приділяє багато уваги процесу відродження народного танцю, створюючи тим самим систему методів вивчення цього процесу. Дослідник часто використовує термінологічний метод, створюючи нові терміносистеми. Осмислюючи процес відродження українських народних танців у Канаді, А. Нагачевський порушує актуальне питання внутрішньої зорієнтованості 
в традиції ретрансляції фольклорних зразків. Учений звертає увагу на існування первісних орієнтирів: на національну компоненту; на рекреаційну компоненту; на видовищність та спіритуалізм. Зорієнтованість на національну компоненту відображається в прагненні ствердження національної приналежності, асоціації індивіда 3 культурною традицією. Рекреаційна компонента спрямована на реалізацію учасниками творчого колективу власних потреб: отримання насолоди від виконання танцю, вдоволення потреб у фізичній активності, релаксації, спілкуванні. Відродження танців у колективах з рекреаційною зорієнтованістю відбувається в закритому середовищі: танці майже ніколи не виконуються на сцені і вирішують лише потреби виконавців. Видовищна орієнтація у збереженні народних танцювальних зразків формується тільки за участю глядачів. У такій ситуації виконання народних танців на сцені $є$ пріоритетним у творчому процесі. Народні танці часто стають заручниками сценічних вимог: їхнє виконання повинне зберігати високу віртуозність та майстерність, утілювати закони драматургії та ін. Інколи відродження народних танців відбувається із спіритуалістичною зорієнтованістю. У цьому разі постійне повторення одних і тих самих рухів необхідне задля отримання сакрального досвіду, возз'єднання з потойбічними силами. Така націленість відродження народних танців у сучасному суспільстві дуже рідко є самоціллю.

Дефіцит спеціальних методів дослідження хореографічного матеріалу може бути компенсований за допомогою залучення дослідницьких прийомів, що використовують у музикознавстві й лінгвістиці. Засвоєння методів цих наукових дисциплін обумовлюється значною спорідненістю, а також багаторічною взаємодією цих жанрів народної творчості (музики, пісні, танцю) в традиційній культурі будь-якого етносу. Серед найактуальніших методів, використання яких набирає прихильників з числа європейських етнохореологів, - метод квантитативного аналізу музично-хореографічного твору, який також використовується в лінгвістиці й музикознавстві. Використання квантитативного методу під час аналізу музичного опусу базується на створенні формули «музичної стопи» (елемент метроритмічної побудови), через підрахунок коротких та довгих складів, що визначає довжину виконання словесного складу; у лінгвістиці його використовують для квантифікації мовних одиниць. Під час дослідження зразків народних танців квантитативний метод впроваджується етнохореологами в процеси вивчення структури хореографічного опусу (від мінімального руху до будь-якої хореографічної форми).

Квантитативний метод уперше був запропонований Н. Саргсян у наукових роботах «Про квантитативний метод аналізу хореографічних і музичних елементів (на прикладі музично-кінетографічних партитур С. С. Джуджева та С. С. Лісіціан)» (Саргсян, 2016), «Методи аналізу хореографічного опусу засобами термінів, що використовуються у музикознавстві» (Саргсян, 2015). Н. Саргсян застосовувала квантитативний метод дослідження до систем запису танцю, розроблених С. Лісіціан «Кінетографія (запис руху)» (Лисициан, 1940) та С. Джуджева «Болгарська народна хореографія» (Джуджев, 1945), адже вони мали паралельно зафіксовані музичну та танцювальну партитури. Паралельна фіксація музично-хореографічного твору зробила проведення квантитативного аналізу можливим. Використання методу в етнохореології базується на співвідношенні формули музичної фрази з хореографічною фразою та особливостями ії структури. Головним завданням було 
виведення формули «танцювальної стопи» (частина метричної побудови рухів) задля подальшого наукового аналізу. 3 огляду на фіксований музичний матеріал і сталу музичну стопу авторка виводила хореографічну стопу засобом підрахування співвідношення коротких та довгих складів-рухів, що визначали довжину розспіву складу-руху. Виведена хореографічна стопа характеризувала особливості виконання руху в часі та просторі, дозволяла визначити його амплітуду.

У свої наукових статтях Н. Саргсян звертала увагу на різні засоби фіксації хореографічних творів. Дослідниця класифікує всі створені системи за основними принципами відображення ними хореографічного тексту, виділяючи «візуальну» та «описову» групи, які мають свої підгрупи (Саргсян, 2016, с. 238). Критикуючи більшість систем запису танцю, Н. Саргсян стверджує: «знакова форма фіксації, що складає з музичним текстом єдину партитуру, $є$ найбільш достовірною та придатною для наукового аналізу». Слід зауважити, що критика можливостей відео-фіксації хореографічного твору, котра базувалась на зауваженнях, висунутих С. Лісіціан, із плином часу дещо втратила свою актуальність. Сьогодні можливості відео-фіксації дають змогу помічати рух одночасно з різних кутів, бачити площу опори та напрямки зміщення ваги тіла. Але відео-фіксація досі не передає м'язової напруги, що супроводжує виконання руху, його силу. Застосування відео-фіксації хореографічних творів з метою їхнього зберігання й ретрансляції можливе лише для танцювальних опусів, що мають сучасне актуальне виконання. Для збереження й дослідження форм народних танців проведення відео-фіксації неможливе, тому що втрачено зв’язки з носіями автентичної культури.

Метод квантитативного аналізу музично-хореографічного твору був використаний у розробленнях Т. Новака «Народний танець в польському культурному каноні. Зародження, генеза, зміни» (Nowak, 2016) та «Польські народні танці як культурний канон - виникнення, генеза, зміни» (Nowak, 2018), під час дослідження канонічних форм польських народних танців. Користуючись системою запису танцю, розробленою Р. Лабаном, Т. Новак створив кінетограми з п’яти основних форм польського народного танцю: полонез, мазур, краков’як, куяв'як та оберек. На основі зробленої паралельної фіксації музичної та хореографічної партитур Т. Новак проводив квантитативний аналіз твору з виявленням особливостей збереження канонічних фольклорних форм у доробках польських балетмейстерів XX-XXI ст.

Проведення квантитативного аналізу танцювального канону народних танців населення Слобожанщини необхідне для його обгрунтування на вищому науковому рівні. В опублікованих матеріалах етнографічних та фольклорних експедицій, які проходили на Слобожанщині з XVIII ст., представлені лише деякі музичні партитури народних танців, що виконувались населенням. Фольклористи фіксували танець за допомогою словесно-описового методу. Такий запис не зберігав жодних практичних відомостей, важливих для проведення наукового аналізу. Характерні для того чи того танцю рухи перелічувались у межах танцювальної фігури, мали фіксовану кількість виконуваних повторів. Також словесно-описовий метод фіксував співвідношення рухів і музичних тактів: перелік рухів додавався до кожного окремого такту, але без фіксації амплітуди руху, сили, часу його виконання, перенесення ваги тулуба, кутів підйому чи згинання ніг та рук тощо. Використання квантитативного методу в процесі опанування стилістикою народного танцю населення Слобожанщини збільшить можливості концептуалі- 
зації танцювального канону, адже пісенний та музичний фольклорний матеріал вчасно був зафіксований дослідниками-фольклористами. Перспективність його впровадження полягає не лише у визначенні особливостей взаємодії музичного та хореографічного творів, але й у можливості створення загальновживаної системи фіксації і окремих рухів, і будь-яких хореографічних форм.

Запровадження квантитативного методу можливе лише за умов графічної презентації народного танцю. Словесних і термінологічних описів стає замало для проведення аналізу на високому рівні. Тому використання системи графічної фіксації народного танцю стає необхідним. Функції системи запису танцю не обмежуються тільки збереженням рухів для їх подальшої репрезентації. За допомогою створених кінетограм можна проводити аналіз хореографічного твору, визначати типові ознаки балетмейстерського почерку або стилю балетмейстерських шкіл Слобожанщини.

Завдяки впровадженню сучасних технологій процес створення танцювальних кінетограм фольклорних танців Слобожанщини значно спрощується. Вагомий внесок у розвиток етнохореології зробили європейські розробники інтелектуального програмного забезпечення, удосконаливши застарілі комп’ютерні програми. Розроблення інтелектуального програмного забезпечення, зорієнтоване на спрощення й прискорення процесу запису танцювальних рухів, розпочалося ще в 1987 р. До останнього часу існувало лише три програми, завданням яких було прискорення креслення кінетограм, а також їх поступове перенесення 3 «паперу» в цифровий вимір. У цих програмах було досить багато недоліків: лише дві з них працювали на базі операційної системи Microsoft Windows, мали обмежений набір символів, не мали функцій додавання нових символів, мали досить незручний інтерфейс. Остання розроблена програма становить найдосконаліше на сьогодні вирішення проблеми фіксації танцювального рух. LabaNotator 1.7.0. працює на операційній системі Microsoft Windows, дає змогу редагувати існуючі та додавати нові символи, створювати кілька шарів символів, які можна потім відділяти, переміщувати й зручно редагувати; програма має багатомовний інтерфейс (англійська, німецька, хорватська, словенська). Теоретична частина програми була розроблена на основі системи запису танцю Р. Лабана.

Актуальним у процесі опанування стилістики фольклорних танців Слобожанщини стає використання термінологічного методу, запровадженого в етнохореологічні розроблення А. Нагачевським. По-перше, за допомогою цього методу уточнюються терміносистеми, що дають змогу уникати наукових непорозумінь під час цитування або в процесі вивчення танцювального фольклору в контексті міждисциплінарних досліджень. По-друге, залучення до процесу вивчення танцювального канону нових методів з їхнім подальшим науковим обгрунтуванням полегшує дослідження деяких аспектів становлення й розвитку цього культурного феномену.

Наукова новизна статті полягає в екстраполяції новітніх методів етнохореології відомих вітчизняних та зарубіжних етнохореологів під час дослідження стилістичних особливостей фольклорних танців Слобожанщини. Уперше проаналізовано алгоритм використання новітніх етнохореологічних методів у процесі опанування стилістикою слобожанського танцювального канону. 
Висновки. Отже, цією студією актуалізується потреба залучення новітніх підходів та методів до системи етнохореологічних досліджень. Проаналізовано методологічний досвід канадських, європейських та вірменських фольклористів-етнохореологів, що дає змогу підвищити рівень наукових досліджень у галузі етнохореології. Додавання цих методів до процесу вивчення слобожанського танцювального канону потребує створення танцювальних кінетограм, співставлення музичних та хореографічних партитур, опанування дослідником механізмів використання квантитативного та термінологічного методів.

\section{СПИСОК БІБЛІОГРАФІЧНИХ ПОСИЛАНЬ}

Джуджев, С.С. (1945). Българска народна хореография. Съ неколко примери изъ мекедонския фолклоръ. София: Министерство на народното просвещение.

Лисициан, С.С. (1940). Кинетография (запись движения). Москва: Искусство.

Нагачевський, А. (2010). Від національного до видовищного: про відродження українського народного танцю в Канаді. Народознавчі Зошити, 3/4, 316-324.

Нагачевський, А., \& Маєрчик, М. (2010). Особливості української фольклористики в Канаді. Народознавчі Зошити, 3-4, 293-309.

Підлипська, А. (2011). Тенденції розвитку наукових досліджень у галузі хореографічної культури в Україні. Культура і сучасність, 2, 207-210.

Саргсян, Н.Г. (2015). Методы анализа хореографического опуса посредством терминов, применяемых в музыкознании. Кантех, 4(65), 236-248.

Саргсян, Н.Г. (2016). О квантитативном методе анализа хореографических и музыкальных элементов (на примере музыкально-кинетографических партитур С. С. Джуджева и С. С. Лисициан). Ученые записки Российской академии музыки имени Гнесиных, $1(16), 13-21$.

Чепалов, О.І. (2018). Хореологія як наука: культурологічні та мистецтвознавчі аспекти. Танццювальні студї, 1, 16-27.

Чепалов, O.I. (2016). Проблеми якості наукового дослідження та достеменності його фахової спеціалізації. Аспекти історичного музикознавства, 8, 128-139.

Чілікіна, Н.О. (2015). Проблематика сучасної хореографічної освіти. Проблеми підготовки сучасного вчителя, 2(12), 298-308.

Шариков, Д.І. (2014). Стилістичні різновиди народного танцю в світі. Вісник Львівського університету, 14, 110-119.

Шариков, Д.І. (2015). Дефініція хореографічної культури: функції та система закономірностей існування. Парадигма познания: гуманитарные вопросы, 1(4), 129-136.

Nowak, T. (2016). Taniec narodowy w polskim kanonie kultury. Źródła, geneza, przemiany. Warszawa: BEL Studio.

Nowak, T. (2018). Polskie tańce narodowe jako kanon kulturowy - wyznaczniki, geneza, przemiany. Studia Chopinowskie, 2. Retrieved from http://studiachopinowskie.pl/pages/issue/63/3.

Rees, V. (2008). Bereznianka: Becoming Symbolic. Народознавчі Зошити, 3-4, 325-331. 


\section{REFERENCES}

Chepalov, O.I. (2016). Problemy yakosti naukovoho doslidzhennia ta dostemennosti yoho fakhovoi spetsializatsii [Problems of scientific research quality and worthiness of his specialty]. Aspekty istorychnoho muzykoznavstva, 8, 128-139 [in Ukrainian].

Chepalov, O.I. (2018). Khoreolohiia yak nauka: kulturolohichni ta mystetstvoznavchi aspekty [Choreology as a science: cultural and art-related aspects]. Tantsiuvalni studii, 1, 16-27 [in Ukrainian].

Chilikina, N.O. (2015). Problematyka suchasnoi khoreohrafichnoi osvity [Problem of modern choreographic education]. Problemy pidhotovky suchasnoho vchytelia, 2(12), 298-308 [in Ukrainian].

Dzhudzhev, S.S (1945). Bulgarian folklore choreography. There are many examples of the Macedonian folklore. Sofia: Ministry of Public Enlightenment [in Bulgarian].

Lisician, S.S. (1940). Kinetografiya (zapis dvizheniya) [Kinetics (motion recording)]. Moscow: Iskusstvo [in Russian].

Nahachevskyi, A. (2010). Vid natsionalnoho do vydovyshchnoho: pro vidrodzhennia ukrainskoho narodnoho tantsiu v Kanadi [From national to spectacular: about the revival of Ukrainian folk dance in Canada]. Narodoznavchi Zoshyty, 3-4, 316-324 [in Ukrainian].

Nahachevskyi, A., \& Maierchyk, M. (2010). Osoblyvosti ukrainskoi folklorystyky v Kanadi. Narodoznavchi Zoshyty, 3-4, 293-309 [in Ukrainian].

Nowak, T. (2016). Taniec narodowy w polskim kanonie kultury. Źródła, geneza, przemiany [National dance in the Polish canon of culture. Sources, genesis, transformations]. Warsaw: BEL Studio [in Polish].

Nowak, T. (2018). Polskie tańce narodowe jako kanon kulturowy - wyznaczniki, geneza, przemiany [Polish national dances as a cultural canon - determinants, genesis, transformations]. Studia Chopinowskie, 2. Retrieved from http://studiachopinowskie.pl/pages/issue/63/3 [in Polish].

Pidlypska,A. (2011). Tendentsii rozvytku naukovykh doslidzhen u haluzi khoreohrafichnoi kultury $\mathrm{v}$ Ukraini [Trends in the development of scientific research in the field of choreographic culture in Ukraine]. Kultura i suchasnist, 2, 207-210 [in Ukrainian].

Rees, V. (2008). Bereznianka: Becoming Symbolic. Narodoznavchi Zoshyty, 3-4, 325-331 [in English].

Sargsyan, N.G. (2015). Metody analiza khoreograficheskogo opusa posredstvom terminov, primenyaemykh v muzykoznanii [Methods of analysis of choreographic opus using terms used in musicology]. Kantekh, 4(65), 236-248 [in Russian].

Sargsyan, N.G. (2016). O kvantitativnom metode analiza khoreograficheskikh i muzykalnykh ehlementov (na primere muzykalno-kinetograficheskikh partitur S.S. Dzhudzheva i S.S. Lisician) [About the quantitative method of analysis of choreographic and musical elements (on the example of music and kinetographic scores of S.S. Dzhudzheva and S.S. Lisician)]. Uchenye zapiski Rossijskoj akademii muzyki imeni Gnesinykh, 1(16), 13-21 [in Russian].

Sharykov, D.I. (2014). Stylistychni riznovydy narodnoho tantsiu v sviti [Stylistic varieties of folk dance in the world]. Visnyk Lvivskoho universytetu, 14, 110-119 [in Ukrainian].

Sharykov, D.I. (2015). Definitsiia khoreohrafichnoi kultury: funktsii ta systema zakonomirnostei isnuvannia [Definition of choreographic culture: functions and system of patterns of existence]. Paradigma poznaniya: gumanitarnye voprosy, 1(4), 129-136 [in Ukrainian]. 